\title{
correspondence
}

\section{Piltdown hoax: new light}

SIR,-If L. B. Halstead (2 November, page 11) had taken the trouble to look a little more closely at the evidence presented in the scientific papers on the Piltdown forgery (as well as in my book, The Piltdown Hoax) he would surely have realised (and this goes also for Mr Richard L. E. Ford) that the late Professor Douglas' arraignment of Professor Sollas is really without any foundation. The "evidence" of Sollas as instigator and co-conspirator with Charles Dawson amounts to very little and that, quite trivial and unconvincing.

Dr Oakley has already, in his letter to The Times (7 November 1978) shown that Douglas was mistaken in thinking that the Mastodon bones he said he gave Sollas were part of the Piltdown assemblage. The receipt by Sollas, according to Douglas' recollection of 68 years ago of a packet of potassium bichromate can hardly be taken as positive evidence for the reasons which Dr Oakley gives in his letter.

Moreover, Douglas should have known that Dawson had admitted to the use of bichromate, that Woodward knew this, and two people told me spontaneously

(that is before the disclosure of the hoax) that they were aware of Dawson's staining activities. Moreover, as Oakley and I have shown, Dawson used a number of different methods of staining and we are left to suppose (on no evidence whatever) that Sollas initiated Dawson in all these methods.

The third item furnished by Douglas in his remembrance of Sollas borrowing apes teeth from the Anatomy Department at Oxford. If Douglas had remembered Sollas borrowing an ape's jaw or even better, an orang's jaw, that would have been rather more interesting, because it was an orang jaw with its molars that was used for the plants at the two Piltdown sites. To say that Dawson needed Sollas as a supplier is sheer guess work and unnecessary at that.

A likely source, as I have pointed out, was Abbott of Hastings, not to mention local museums and even straightforward purchase. A fourth item of "evidence" is the Sherbourne horse's head. For Douglas to say that this little curiosity (which cannot in fact be brought home to Sollas) is "an almost similar act" to that of the elaborate Piltdown Forgery is quite fatuous,

The motive attributed to Sollas for the humiliation of Smith-Woodward does not make sense. If his plan was to "expose" Smith-Woodward's gullibility and incompetence, why should he have so firmly supported the new Eoanthropus dawsoni in the first place? Why did he not wreak his vengeance by exposing the forgery at any time after Dawson's death in 1916? Halstead argues disingenuously that once Dart had discovered Australopithecus Sollas would have known that it was only a matter of time before Piltdown Man was exposed. But if Sollas was so sure about the status of A ustralopithecus africanus in relation to
Piltdown, surely Dart's discovery provided the perfect opportunity (from 1925 onwards) to expose both Piltown and Smith-Woodward.

The truth is that none of the leading palaeontologists of the day, including Dart and Broom (despite their many australopithecine discoveries), nor Leakey, nor Le Gros Clark, could see that Australopithecus made Piltdown Man impossible and (ergo) fraudulent. The reasons for this myopia, I have discussed elsewhere. A hint from Sollas or later Douglas, to any one of these would have been sufficient. Halstead is simply arguing from hindsight in suggesting that Sollas went to his grave rubbing his hands in anticipatory glee.

In my book I point out in some detail that a "mastermind" to guide Dawson through all the years of the complicated sequence of the events at Barkham Manor and Sheffield Park would need to be of Mephistophelean calibre. It would be tedious to repeat here all that is implied in asserting, or postulating, a continuous connection between Dawson and Sollas. Douglas and his sponsors do not even begin to face up to this. In the case of Sollas it would be quite as difficult a task as that which faced the recent accuser of Elliott Smith. Messrs. Halstead and Ford might care to look for proof of Sollas' alleged activities in the light of the arguments in my paper on Elliott Smith and Piltdown (Symp. Zool. Soc. Lond. no. 33, 23-26; 1973).

One thing the late Professor Douglas has succeeded in doing. He has certainly added a mystery of his own devising to the Piltdown saga - why should Douglas on such incredibly weak evidence take the trouble to besmirch Sollas' reputation? Yours faithfully,

J. S. WEINER

The Athenaeum,

Pall Mall,

London

\section{Proliferation}

SiR,-In your article 'Is Proliferation Unstoppable' (26 October, page 681) you say that after the May 1975 Review Conference of the Treaty on the Non-Proliferation of Nuclear Weapons ". . . no outsider proceeded to sign". You cite this as evidence that "the NPT could hardly be said to be an unqualified success".

The facts are that during and after the conference eleven additional states joined the NPT. The new states included Libya, Venezuela, Japan, Switzerland and Portugal. A growth of $14 \%$, including some important states, is not bad going. The treaty now has 104 members and Indonesia and Turkey are in the process of ratification.

Only 13 non-nuclear weapon states that have any significant nuclear plant remain outside the treaty; they include several of those mentioned in your article. However, in eight of these 13 every nuclear plant of which we are aware is under safeguards pursuant to
non-NPT arrangements (like the German/Brazilian agreement). Only five non-nuclear weapon states have unsafeguarded plant--these include

India, Israel and South Africa.

We agree that everything should be done to strengthen the non-proliferation regime, but one should not denigrate the considerable success of the treaty. A few years ago, German and Japanese ratification was by no means certain; now almost every leading industrial non-nuclear weapon state is a party. Moreover, IAEA safeguards have become much more effective and stringent in recent years. Yours faithfully, HANS-Friedrich Meyer

IAEA, Vienna, Austria.

\section{Responsible statements}

SIR,-Though Nature is to be applauded for welcoming presentation of alternative views on controversial issues, I would think that the nature of the journal requires the editors to hold authors to a reasonable standard of responsibility, even on issues that evoke ideological conflicts. I therefore wonder why you lend the dignity of your pages to such statements as the following, in an article by Jonathan King (2 November, page 7): "Now we don't have a law in the United States that keeps anybody from introducing any gene into an epidemic strain of E. coli or salmonella or Shigella; and there are forces in that direction because of patents. If somebody else has a patent on making insulin in E. coli and you recognise that market what do you do?"

Yours faithfully, Bernard D. Davis

Harvard Medical School,

Boston, Ma., USA

\section{Helpful oil companies}

SIR,--The article on wave energy (30 November, page 433), gives a poor impression of the helpfulness of the oil companies, which I would like to correct.

UK OOA wave data is commercial and confidential, and there was a time when Wavepower Limited could not have access to it. However, that access was cleared some time ago via the Department of Energy-I was misinformed, and misled your reporter.

Nevertheless you misrepresent both the oil companies and myself when you say that I have been unable even to arrange a visit to one of the platforms. My enquiry at the conference was the first time of asking, and I have already had two offers in reply. Yours faithfully,

Wavepower Limited,

Southampton, $U K$. 